\title{
Model Bimbingan Kelompok dalam Menggunakan Metode Role Playing untuk Mengurangi Kecemasan Berkomunikasi pada Peserta Didik
}

\author{
Dina Anggrawati ${ }^{1 凶}$, Fitria Kasih ${ }^{2}$ \\ (1) Bimbingan Konseling Islam, STKIP PGRI Sumatera Barat
}

$\triangle$ Corresponding author

(dinanaggrawati21@gmail.com)

\begin{abstract}
Abstrak
Penelitian ini dilatarbelakangi adanya kecemasan berkomunikasi peserta didik yang belum tercapai dan ada Guru Bimbingan Koseling belum menggunakan metode bervariasi dalam melaksanakan bimbingan kelompok. Tujuan penelitian adalah mendeskripsikan: a).Profil tingkat kecemasan berkomunikasi peserta didik, b).Pelaksanaan bimbingan kelompok oleh guru BK mengunakan metode role playing. c).Model rancangan layanan bimbingan kelompok dengan menggunakan metode role playing dalam membantu mengurangi tingkat kecemasan berkomunikasi peserta didik. Penelitian ini dilakukan dengan menggunakan mixed method.Populasi penelitian saya 30 peserta didik. Teknik pengambilan sampel menggunakan Total sampling dengan 30 partisipan instrumen yang digunakan yaitu angket dan wawancara sedangkan untuk analisis data menggunakan presentase dan reduksi data, penyajian data penarikan kesimpulan atau verifikasi. Hasil penelitian tentang Kecemasan Berkomunikasi peserta didik XI MIPA SMA PGRI 2 Padang dilihat dari: 1)Secara umum profil keterampilan komunikasi peserta didik pada kategori cukup tinggi 2) Pelaksanaan layanan bimbingan kelompok dalam mengurangi kecemasan berkomunikasi peserta didik yang dilakukan guru BK belum memberikan hasil yang maksimal karena selama ini guru Bk kurang memberikan metode-metode yang bervariasi.3)Model rancangan layanan bimbingan kelompok dalam membantu mengurangi kecemasan berkomunikasi. dapat diambil kesimpulan sebagai berikut: kecemasan berkomunikasi peserta didik berada pada kategori cukup tinggi dan belum berada pada kategori sangat rendah.
\end{abstract}

Kata Kunci: Bimbingan Kelompok, Metode Role Playing, Kecemasan Berkomunikasi.

\begin{abstract}
This research is motivated by the students' communication anxiety that has not been achieved and there are Counseling Guidance Teachers who have not used varied methods in implementing group guidance. The purpose of this research is to describe: a). The profile of students' communication anxiety level, b). The implementation of group guidance by BK teachers uses the role playing method. c). The design model of group guidance services using the role playing method in helping reduce the level of communication anxiety of students.b This research was conducted using a mixed method. My research population was 30 students. The sampling technique used total sampling with 30 participants, the instruments used were questionnaires and interviews, while for data analysis using percentages and data reduction, data presentation of conclusions or verification. The results of the study on Communication Anxiety of XI MIPA students at SMA PGRI 2 Padang were seen from: 1) In general, the communication skill profile of students in the fairly high category 2) Implementation of group guidance services in reducing students' communication anxiety by BK teachers did not give maximum results. Because so far counselling teachers have not provided varied methods. 3) The design model of group guidance services in helping to reduce communication anxiety. The following conclusions can be drawn: students' communication anxiety is in the fairly high category and not yet in the very low category.
\end{abstract}

Keywords: Group Guidance, Role Playing Method, Communication Anxiety. 


\section{PENDAHULUAN}

Pendidikan merupakan suatu elemen yang sangat penting dalam hidup manusia yang dapat mempengaruhi kecerdasan intelektual, emosional dan spiritual. Ketiga kecerdasan tersebut saling mempengaruhi dalam aspek kepribadian manusia serta ketiga kecerdasan tersebut juga diperoleh salah satunya melalui dunia pendidikan. Pendidikan adalah suau energi yang dapat mempengaruhi aspek kepribadian pada diri manusia dengan tujuan memuliakan itu sendiri sebagai ciptaan Allah.

Pendidikan itu merupakan suatu pembelajaran yang diberikan oleh seseorang Guru yang dapat membantu individu dari yang tidak tau menjadi tau, dari yang tidak pandai menjadi pandai, dari yang tidak mengalami menjadi paham. Pendidikan pada hakkatnya merupakan suatu proses yang membantu menumbuh kembangkan kecerdasan manusia itu sendiri terutama dimasa remaja.

Tohirin (2011: 26) menyatakan proses pendidikan sendiri juga diperlukan adanya bimbingan dan konseling di dalamnya yang nantinya akan dilaksanakan oleh guru $\mathrm{Bk}$, dimana bimbingan dan konseling sendiri merupakan proses bantuan atau pertolongan yang diberikan oleh pembimbing atau konselor kepada individu atau konseli melalui pertemuan tatap muka.

atau pertolongan yang sistematis dari pembimbing atau konselor kepada konseli atau siswa melalui pertemuan tatap muka atau hubungan timbal balik antara keduanya untuk mengungkapkan masalah konseli sehingga konseli mampu melihat masalah sendiri, mampu menerima dirinya sendiri sesuai dengan potensinya, dan mampu memecahkan sendiri masalah yang dihadapinya.

Sutirna (2013: 8) bahwa tujuan dari bimbingan dan konseling sendiri agar nantinya konseli dapat merencanakan kegiatan penyesuaian studi dalam hal pengembangan karir serta kehidupannya dimasa yang akan datang, mengembangkan seluruh potensi dan kekuatan yang dimilikinya seoptimal mungkin, menyesuaikan diri dengan lingkungan pendidikan, lingkungan masyarakat dan lingkungan kerja, mengatasi hambatan dan kesulitan yang dihadapi dalam studi, penyesuaian dalam lingkungan pendidikan, masyarakat maupun lingkungan kerja. Hal ini juga dilakukan untuk membantu memandirikan peseta didik terlebih lagi dalam suasana perkembangan yang dinilai menemui banyak masalah, di antaranya masalah siswa yang cemas dalam berkomunikasi. Yang mana dimasa pandemi saat sekarang ini banyak peserta didik yang gagal dalam berkomunikasi baik dengan guru maupun teman sebayanya. Terkususnya kelas XI yang masih banyak melu bertanya dengan temannya serta gurunya sendiri dan sekarangpun peserta didik belum mulai masuk sekolah namun bisa kesekolah dengan pertokol kesehatan dan memakai baju bebas dan SMA PGRI 2 Padang mengadakan sift masuk sekolah untuk pengantaran tugas. Saat peneliti melakukan menanyakan kepada mereka mengatakan bahwa mereka malu saat berkomunikasi dengan teman atau gurunya, mereka beranggapan bahwa jika mereka berbicara takut salah dan ditertawakan oleh temannya.

Disini salah satu tujuan siswa belajar adalah untuk menguasai kemampuan komunikasi dengan baik agar proses belajar dan mengajar dikelas dapat berjalan dengan lancar. Sesorang yang cemas berkomunikasi akan menarik diri dalam peraulan, bahkan seseorang yang cemas dalam berkomunikasi mereka kurang mampu berkomunikasi didepan umum mempunyai kemungkinan besar untuk mereka berprestasi karena tidak dapat mempengaruhi orang lain, walaupun mereka mempunyai ide yang sangat bagus. Atkinson (2001 : 212) kecemasan adalah emosi yang tidak menyenangkan yang ditandai dengan istilah-istilah seperti "kekhawatiran","keprihatinan" dan "rasa takut", yang kadang-kadang dialami dalam bentuk tingkat yang berbeda-beda.

Atkinson (2001: 212) kecemasan berkomunikasi didalam ilmu komunikasi rasa malu atau kecemasan tersebut dikenal dengan Communication Apprehension (CA), yaitu rasa cemas dengan tindak komunikasi yang akan dan sedang dilakukan dengan orang lain. Kecemasan dalam berkomunikasi ini dalam realitasnya merupakan suatu bentuk perilaku yang norma dan bukan menjadi persoalan yang serius bagi setiap orang sepanjang individu tersebut mampu mereduksi Communication Apprehension (CA) yang dihadapinya, sehingga tingkat kecemasannya tidak mengganggu atau berpengaruh terhadap tidak berkomunikasi yang dilakukannya. Namun, apabila kecemasan tersebut sudah bersifat patologis, maka individu tersebut akan menghadapi permasalahan pribadi yang bersifat serius, seperti misalnya usaha untuk selalu mengindari berkomunikasi dengan orang lain atau di depan umum yang pada akhirnya akan mengarah pada ketidak inginan individu tersebut untuk berkomunikasi. 
Jadi, fokus teori ini adalah mengganti cara-cara berfikir yang tidak logis menjadi logis. Untuk mencegahnya bimbingan dan konseling mempunyai 10 layanan salah satunya layanan bimbingan kelompok. Prayitno,Dkk (2004: 307-308) Bimbingan kelompok merupakan layanan yang diberikan pada sekelompok orang. Dimana layanan bimbingan kelompok ini merupakan pengembangan keterampilan berkomunikasi dan berinteraksi sosial bagi klien setelah menerima layanan konseling perorangan.Bimbingan kelompok adalah untuk memungkinkan siswa secara bersama-sama memperoleh berbagai bahan dari nara sumber (terutama dari Guru Pembimbing) yang bermanfaatkan untuk kehidupan sehari-hari baik sebagai individu maupun sebagai pelajar,anggota keluarga, dan masyarakat. Masalah yang dibahas adalah masalah perorangan yang muncul dalam kelompok itu, yang meliputi berbagai masalah dalam segenap bidang bimbingan (yaitu bidang bimbingan pribadi,sosial,belajar, dan karier).

Dalam penelitian ini peneliti menggunakan saalah satu teknik yaitu teknik Role Playing dimana berdasarkan kajian literatur di dalam bimbingan dan konseling terdapat banyak teknik yang dapat digunakan untuk membantu siswa dalam meningkatkan keterampilan salah satunya adalah teknik Role Playing. Romlah (Dharmayanti,2013)Role Playingmerupakan salah satu teknik yang telah diteliti oleh para ahli yang bekerja dibidang penyelenggaraan latihan-latihan. Para ahli telah membuktikan bahwa Role Playing merupakan teknik yang bermutu. Para ahli psikologi behavior menggunakan teknik tersebut untuk melatih ahli komunikasi atau ahli hubungan interpersonal dalam lingkungan.

Jackson (2011: 775-780) Role Playing sangat membantu peserta didik yang sulit terlibat aktif berkomunikasi dalam proses pembelajaran di sekolah dengan cara yang tidak menimbulkan kecemasan. Selain itu Role Playing juga memberikan manfaat kepada pendidik dalam hal bagaimana dan kapan sebaiknya memberikan umpan balik dalam proses pembelajaran agar terdengar menyenangkan untuk peserta didik. Selain itu, Najlatun \& Galih (2013: 61-78) dalam penelitiannya menemukan bahwa Role Playingdapat secara efektif meningkatkan kemampuan komunikasi siswa.

Selain efektif untuk meningkatkan komunikasi, teknik Role Playingjuga telah teruji efektif digunakan pada berbagai macam permasalahan, misalnya berdasarkan penelitian yang dilakukan oleh Larson dan Brown (2007) yang menemukan bahwa keterampilan emosi remaja menjadi lebih kuat melalui program teater sekolah. Program teater tersebut menggunakan teknik Role Playinguntuk melati para remaja menggunakan emosi positif mereka menjadi motivasi dalam mengerjakan tugas. Jadi dapat disimpulkan bahwa permasalahan kecemasan dengan teknik Role Playinglebih efektif menggunakan layanan konseling kelompok.

Berdasarkan wawancara dengan Guru BK SMA PGRI 2 Padang pada Tanggal 19 juli 2021, bahwa beberapa siswa masih ada kecemasan berkomunikasi baik itu dengan guru mata pelajaran maupun teman-teman sebayanya, terkusus kelas XI yang masih malu bertanya dengan temantemannya, menurut beliau mungkin karena pandemi Covid-19 dan sekolahpun diharuskan untuk bergantian pengantaran tugas. Sehingga hal ini akan berdampak kepada siswa itu sendiri dalam melaksanakan proses belajar-mengajar.

Hal yang sudah dilakukan oleh Guru BK SMA PGRI 2 Padang yaitu beliau meminta peserta didik untuk aktif didalam kelas dan saling beragumen didepan kelas atau dharing sekalipun dengan memberikan sebuah reword, serta guru bimbingan dan konseling memberikan arahan kepada peserta didik bahwasanya kecemasan berkomunikasi dapat menghambat mereka semua untuk sukses dan berkarir. Dan pelaksaan Bimbingan kelompok bersifat menonton sehingga peserta didik kurang aktif dalam pelaksanaan layanan.Berdasarkan wawancara dengan peserta didik kelas XI pada Tanggal 19 juli 2021, bahwa mereka masih merasa takut dan malu berkomunikasi dengan guru maupun teman sebayanya, mereka merasa kurang percaya diri walaupun mereka sudah mengenal teman dan gurunya. Mereka cemas saat menanyakan sesuatu yang mereka tidak paham dan takut untuk bertanya.

Selanjutnya hasil Observasi dengan peserta didik kelas XI di SMA PGRI 2Padang pada Tanggal 10 juli 2021 peneliti menemukan bahwa masih ada dari mereka merasa cemas berkomunikasi dengan teman maupun gurunyaa, mereka merasa takut jika apa yang ditanyakan nantinya salah dan akan ditertawakan oleh teman-teman lainnya, merekapun lebih memilih mencari sendiri dan tidak ingin bertanya dengan teman ataupun gurunya. Guru BK telah melaksanakan segala upaya untuk meningkatkan kecemasan berkomunikasi peserta didik dengan melakukan beberapa layanan BK 
seperti layanan informasi, layanan orientasi dan layanan Bimbingan Kelompok terhadap peserta didik, namun upaya yang dilakukan oleh Guru BK masih belum tercapai dengan baik dan masih ada Guru BK belum menggunakan teknik layanan Bimbingan Kelompok dengan baik.

Melihat situasi dan keadaan di atas, membuat penulis tertarik untuk meneliti "Model BimbinganKelompok dengan Menggunakan Metode Role Playing untuk Mengurangi Kecemasan Berkomunikasi Peserta Didik Kelas XIdi SMA PGRI 2 Padang."

\section{METODE PENELITIAN}

Metode penelitian yang digunakan adalah Mixed Method jenis analisis deskriptif. Subjek Penelitian ini adalah Kelas XI MIPA. Penentuan subjek penelitian ini dengan menggunakan teknik Total Sampling. Instrumen yang digunakan dalam penelitian ini adalah Angket dan wawancara yang disusun sendiri dan telah diuji validitas dan reliabilitasnya. Teknik analisis data yang digunakan adalah reduksi data, penyajian data, penarikan kesimpulan.

\section{HASIL DAN PEMBAHASAN \\ Deskripsi Data}

Data dalam penelitian ini merupakan jumlah skor presentase siswa yang berada pada tingkat kecemasan berkomunikasi.

\section{Tabel 1. rekapitulasi hasil penelitian model layanan bimbingan kelompok dalam kecemasan berkomunikasi peserta didik di SMA PGRI 2 Padang}

\begin{tabular}{|c|c|c|c|c|c|c|c|c|}
\hline \multirow{2}{*}{ Variabel } & \multirow{2}{*}{$\begin{array}{c}\text { Sab } \\
\text { Variabel } \\
\end{array}$} & \multirow{2}{*}{ Indikater } & \multicolumn{5}{|c|}{ Jumlab 56} & \multirow{2}{*}{$\begin{array}{l}\text { Ketera } \\
\text { ngax } \\
\end{array}$} \\
\hline & & & $\overline{S T}$ & $\bar{T}$ & $\mathrm{CT}$ & $\overline{\mathrm{R}}$ & SR & \\
\hline \multirow{12}{*}{$\begin{array}{l}\text { Recemas } \\
\text { an } \\
\text { Berleoms } \\
\text { nileasi }\end{array}$} & & & $0 \%$ & $6,67 \%$ & $86,66 \%$ & $6,67 \%$ & $0 \%$ & $\begin{array}{l}\text { Coves } \\
\text { tingei }\end{array}$ \\
\hline & \multirow{2}{*}{$\begin{array}{l}\text { Kemamp } \\
\text { wan } \\
\text { mengend } \\
\text { allean } \\
\text { fecemas } \\
\text { an } \\
\text { berlooms } \\
\text { nXeasi }\end{array}$} & & $0 \%$ & $\begin{array}{c}23,35 \\
\%\end{array}$ & $70,00 \%$ & $6,67 \%$ & $0 \%$ & $\begin{array}{l}\text { Cocoses } \\
\text { tingsi }\end{array}$ \\
\hline & & $\begin{array}{l}\text { Mengendalkan rasa } \\
\text { cemas dan takest yang } \\
\text { mpocul pada diri }\end{array}$ & $0 \%$ & $\begin{array}{c}10,00 \\
\%\end{array}$ & $50,00 \%$ & $36,67 \%$ & $3,33 \%$ & $\begin{array}{l}\text { Coleng } \\
\text { tingsi }\end{array}$ \\
\hline & \multirow{3}{*}{$\begin{array}{l}\text { bemamp } \\
\text { wan } \\
\text { mengeles } \\
\text { prexilean } \\
\text { becemas } \\
\text { an } \\
\text { bombeil } \\
\text { asi }\end{array}$} & & $0 \%$ & $3,33 \%$ & $83,34 \%$ & $13,33 \%$ & $0 \%$ & $\begin{array}{l}\text { Cowesp } \\
\text { tinnesi }\end{array}$ \\
\hline & & 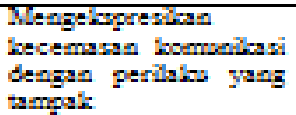 & $3,33 \%$ & $\begin{array}{c}33,33 \\
\%\end{array}$ & $63,34 \%$ & $30,00 \%$ & $0 \%$ & $\begin{array}{l}\text { Colong } \\
\text { tingsi }\end{array}$ \\
\hline & & 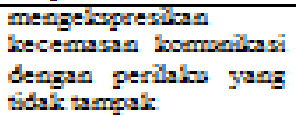 & $0 \%$ & $\underset{\%}{23,33}$ & 70,0096 & $6,67 \%$ & $0 \%$ & $\begin{array}{l}\text { Colase } \\
\text { tingsi }\end{array}$ \\
\hline & \multirow{3}{*}{$\begin{array}{l}\text { bemamp } \\
\text { wan } \\
\text { mengend } \\
\text { allean } \\
\text { becemas } \\
\text { an } \\
\text { vendiri }\end{array}$} & & $3,33 \%$ & $\begin{array}{c}23,34 \\
\%\end{array}$ & $50,00 \%$ & $20,00 \%$ & $3,33 \%$ & $\begin{array}{l}\text { Cotesp } \\
\text { tingsi }\end{array}$ \\
\hline & & 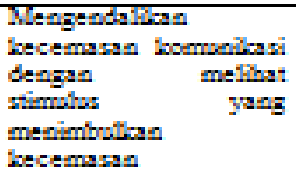 & $3,33 \%$ & $\begin{array}{c}10,00 \\
\%\end{array}$ & $40,00 \%$ & $40,00 \%$ & $6,67 \%$ & $\begin{array}{l}\text { Colos } \\
\text { tingsi } \\
\text { dan } \\
\text { Rendah }\end{array}$ \\
\hline & & $\begin{array}{l}\text { mengendakgan } \\
\text { becemasan fombolloasi } \\
\text { dengan perilake }\end{array}$ & $0 \%$ & $\begin{array}{c}16,67 \\
\%\end{array}$ & $45,67 \%$ & $33,33 \%$ & $0 \%$ & $\begin{array}{l}\text { Colvog } \\
\text { tingsi }\end{array}$ \\
\hline & \multirow{3}{*}{$\begin{array}{l}\text { Gemamp } \\
\text { wan } \\
\text { mendeng } \\
\text { arlan } \\
\text { dan } \\
\text { memaba } \\
\text { mi crang } \\
\text { lain }\end{array}$} & & $0 \%$ & $3,33 \%$ & $63,33 \%$ & $33,34 \%$ & $0 \%$ & $\begin{array}{l}\text { Colove } \\
\text { tingsi }\end{array}$ \\
\hline & & $\begin{array}{l}\text { Mendengarkan orang } \\
\text { lain dengan bax }\end{array}$ & $0 \%$ & $0 \%$ & $26,67 \%$ & $56,66 \%$ & $\begin{array}{c}16,67 \\
\%\end{array}$ & Readah \\
\hline & & $\begin{array}{l}\text { Memahami diri sendiri } \\
\text { dan orang lain dengan } \\
\text { baxt }\end{array}$ & $3,33 \%$ & $\begin{array}{c}43,34 \\
\%\end{array}$ & $\$ 0,0096$ & $0 \%$ & $3,33 \%$ & $\begin{array}{l}\text { Culevep } \\
\text { tingsi }\end{array}$ \\
\hline
\end{tabular}

Berdasarkan Tabel 2 di atas dapat dilihat bahwa presentase kecemasan berkomunikasi cukup tinggi. Selanjutnya kecemasan berkomunikasi sesuai dengan hasil deskripsi data sebelumnya diperkuat dengan grafik berikut. 


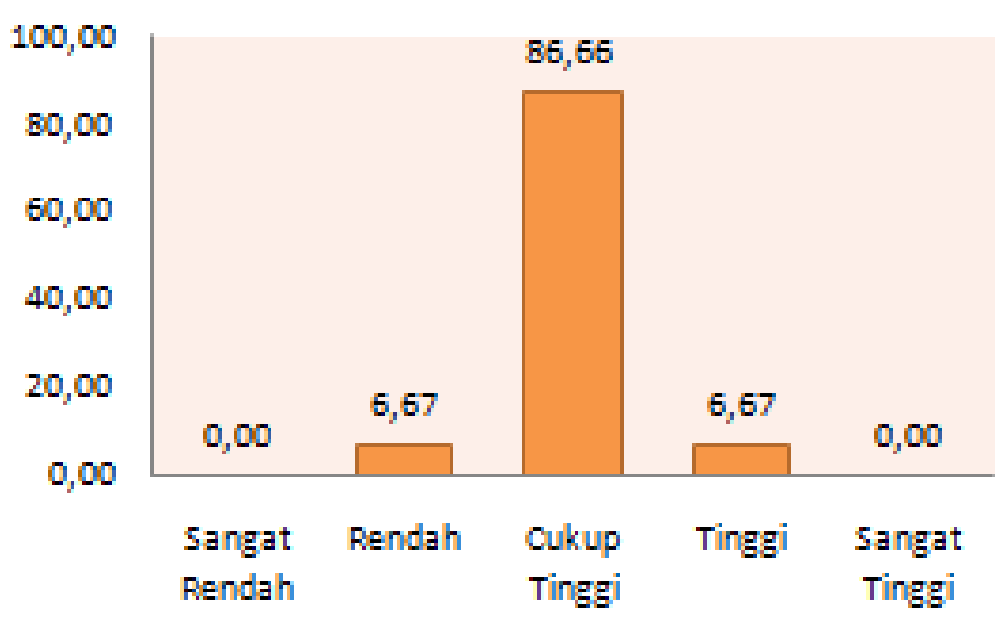

\section{Grafik 1 : Grafik Profil Kecemasan Berkomunikasi Peserta Didik di SMA PGRI 2 Padang Kelas XI MIPA}

Berdasarkan Grafik 1 di atas, diketahui bahwa kecemasan berkomunikasi peserta didik di SMAPGRI 2 Padang kelas XI Mipa secara umum berada kategori cukup tinggi yaitu 86,66\%.

\section{Pengujian Hipotesis}

\section{Table 2. Rekapitulasi Hasil Penelitian tentang Bimbingan Kelompok}

\begin{tabular}{|c|c|c|}
\hline NO & Pertanyaan & Deskripsi analisa \\
\hline 1 & $\begin{array}{l}\text { Bentuk bimbingan kelompok } \\
\text { yang bapak ibu berikan dalam } \\
\text { membantu } \\
\text { mengurangikecemasan } \\
\text { berkomunikasi? }\end{array}$ & $\begin{array}{l}\text { Guru BK memberikan beberapa materi } \\
\text { yang berkaitan dengan kecemasan } \\
\text { berkomunikasi, diskusi, pemberian } \\
\text { bebarapa contoh pengalaman }\end{array}$ \\
\hline 2 & $\begin{array}{lrr}\text { Bentuk metode } & \text { yang } & \text { pernah } \\
\text { bapak ibu berikan dalam } \\
\text { bimbingan kelompok untuk } \\
\text { membantu } & \text { mengurangi } \\
\text { kecemasan } & \text { berkomunikasi } \\
\text { peserta didik? } & \end{array}$ & \begin{tabular}{lrr} 
Tahap-tahap & dalam & \multicolumn{2}{c}{ pelakasanaan } \\
bimbingan & kelompok & sesuai dengan \\
pelaksanaan & layanan & bimbingan \\
kelompok. & &
\end{tabular} \\
\hline 3 & $\begin{array}{l}\text { bentuk yang bapak ibu lakukan } \\
\text { dalam membantu mengurangi } \\
\text { kecemasan } \\
\text { berkomunikasipeserta didik? }\end{array}$ & $\begin{array}{l}\text { Upaya yang kami lakukan adalah } \\
\text { dengan memberikan materi yang } \\
\text { berkaitan dengan } \\
\text { berkomunikasi peserta didik }\end{array}$ \\
\hline 4 & $\begin{array}{l}\text { Bentuk kendala bapak ibu dalam } \\
\text { melaksanakan bimbingan } \\
\text { kelompok? }\end{array}$ & $\begin{array}{l}\text { Kendala yang kami laksanakan dalam } \\
\text { menjalankan bimbingan kelompok } \\
\text { adalah keterbatasan waktu dan tempat, } \\
\text { serta kurang variasi dalam proses } \\
\text { pelaksanaan bimbingan kelompok } \\
\text { sehingga membuat peserta didik } \\
\text { menjadi bosan dan interaksi terjadi pun } \\
\text { kurak efektif }\end{array}$ \\
\hline 5 & $\begin{array}{l}\text { Bentu upaya bapak ibu } \\
\text { mengatasi kendala dalam } \\
\text { pemberian layanan bimbingan } \\
\text { kelompok? }\end{array}$ & $\begin{array}{l}\text { Upaya yang sejauh ini kami lakukan } \\
\text { adalah dengan memanfaatkan } \\
\text { keterbatasan yang kami miliki }\end{array}$ \\
\hline
\end{tabular}

Berdasarkan hasil temuan di atas, maka dapat peneliti simpulkan bahwa bimbingan kelompok yang pernah guru BK berikan di SMA PGRI 2 Padang berupa bimbingan kelompok yang dilakukan secara diskusi, pemberian contoh pengalaman, dan materi yang berkaitan dengan kecemasan berkomunikasi, kendala yang di temui dalam pelaksanaan bimbingan kelompok adalah kurang jam umtuk bisa melaksanakan bimbingan kelompok. 


\section{Pembahasan}

Sesuai dengan instrumen yang telah dijalankan maka, penelitian ini dideskripsikan data tentang kecemasan berkomunikasi peserta didik di SMA PGRI 2 Padang. Yang akan dilihat sebagai berikut:

\section{Profil Kecemasan Komunikasi Peserta Didik}

Berdasarkan hasil pengolahan data tentang kecemasan berkomunikasi peserta didik secara umum berada kategori sangat tinggi tidak ada atau (0\%), selanjutnya pada kategori tinggi 2 orang peserta didik dengan presentase (6,67\%), pada kategori cukup tinggi 26 orang peserta didik dengan presentase (86,67\%), untuk kategori rendah 2 orang peserta didik dengan presentase $(6,67 \%)$, dan kategori sangat rendah tidak ada atau (0\%)

Yusuf dan Ridwan (Dedi Saputra,2020:4) menyatakan komunikasi adalah proses yang integral dalam menjalankan dalam menjalankan fungsi-fungsi manajemen, selain itu komunikasi merupakan input atau output dalam proses manajemen. Thomas I.Harries \& Mart d.Delson (2008:13) komunikasi adalah proses. Poppy Ruliana \& Puji Lestari (2019:179) komunikasi adalah sebuah aktifitas yang paling dominan yang terjadi didalam lingkungan kerja.

Berdasarkan uraian diatas dapat disimpulkan bahwa komunikasi merupakan proses menciptakan dan berbagi ide, informasi, pandangan, fakta, perasaan diantara orang-orang untuk mencapai pemahaman bersama.

Berdasarkan hasil wawancara dengan informan kunci (Guru bimbingan dan Konseling) beserta dengan informan tambahan (Guru Bimbingan dan Konseling dan peserta didik) yang dilakanakan pada tanggal 30-31 Agustus di SMA PGRI 2 Padang dapat di peroleh bahwa kecemasan berkomunikasi peserta didik di SMA PGRI 2 Padang di kelas XI Mipa pada kecemasan berkomunikasi, malu dan takut.

Hasil wawancara peniliti lakukan dengan guru Bimbingan dan Konseling terkait dengan layanan bimbingan kelompok yang pernah diberikan terdapat guru Bimbingan dan Konseling yang memberikan layanan bimbingan kelompok tidak menggunkan metode bervariasi dan disini peneliti merancang program layanan bimbingan kelompok yang dapat membantu guru bimbingan konseling dalam mencapai kecemasan berkomunikasi peserta didik. Dalam merancang program layanan bimbingan kelompok yang berkaitan dengan kecemasan berkomunikasi yang belum terpenuhi, guru Bk dalam melaksanakan layanan bimbingan kelompok untuk merancang program layanan bimbingan kelompok dari situlah peneliti melakukan need asesment.

\section{Pelaksanaan Bimbingan Kelompok}

Pada penelitian ini temuan data yang peniliti kemukakan adalah data yang bersifat deskriptis analisis, yaitu model rancangan layanan bimbingan kelompok menggunakan metode Role Playing dalam membantu mengurangi peserta didik. Data yang didapatkan melalui hasil wawancara dengan 1 orang guru bimbingan dan konseling yaitu sebagai informan kunci dan 1 orang guru informan tambahan dan peserta didik.

Berdasarkan hasil temuan yang peneliti dapatkan dari wawancara mengenai kecemasan berkomunikasi peserta didik di lakukan secara berkala mulai dari tanggal 30-31 Agustus 2021, hasil penyajian data dari temuan peneliti di tunjukan untuk melihat kecemasan berkomunikasi peserta didik kelas XI Mipa SMA 2 Padang dan pemberian layanan bimbingan kelompok dan metode apa saja yang di gunakan.

\section{Rancangan Model Layanan Bimbingan Kelompok dalam Mengurangi Kecemasan Berkomunikasi Peserta Didik di SMA PGRI 2 Padang}

Berdasarkan hasil penelitian di atas bahwa kecemasan berkomunikasi peserta didik berada pada kategori cukup tinggi. Perlu dirancang layanan bimbingan kelompok menggunakan metode role playing dengan topik kecemasan berkomunikasi. Pembahasan kecemasan berkomunikasi terdapat 4 sub variabel dan 7 indikator.

Setelah peneliti melakukan wawancara, peneliti menemukan bahwa guru bimbingan dan konseling hanya mengamati perilaku peserta didik dan jarang menggunakan instrument-instrumen 
dalam mencari need assessment peserta didik, begitu juga dalam pemberian layanan guru BK juga jarang menggunakan metode atau teknik dalam menajalankan layanan, contohnya pada pelaksanaan layanan bimbingan kelompok yang hanya di lakukan sesuai standar saja tanpa ada variasi ataupun penambahan metode dalam pelaksanaannya. Hal ini terjadi di karenakan minimnya jam BK di SMA PGRI 2 Padang.

\section{Rasionalisasi}

Paradigma bimbingan dan konseling pada saat ini berorientasi pada pengenalan potensi , kebutuhan, dan tugas perkembangan serta pemenuhan kebutuhan dan tugas-tugas perkembangan tersebut. Alih-alih memberikan pelayanan bagi peserta didik yang bermasalah ,pemenuhan perkembangan optimal dan pencegahan terjadinya masalah individu merupakan kegiatan yang urgen pada awal pemberian layanan. Bimbingan ini dan konseling ini bertujuan pada mengenali kebutuhan peserta didik, orang tua dan sekolah.

Bimbingan dan konseling di sekolah memiliki perenan penting dalam membantu peserta didik dalam mencapai tugas-tugas perkembangan sebagaimana tercantum pada standar kopetensi kemandirian peserta didik dan kopetensi dasar (SSKPD). Dalam mendukung upaya mendukung pencapain tugas perkembangan tersebut, program bimbingan dan konseling dilaksanakan secara utuh dan kolaboratif dengan seluruh stakeholder sekolah.

\section{Pembahasan}

Pada bagian ini akan di paparkan pembahasan berdasarkan analisis penafsiran, temuan penelitian mengenai Model Rancangan Layanan Bimbingan Kelompok dengan menggunakan Metode Role Playingdalam mengurangi kecemasan berkomunikasi Peserta Didik (Studi Deskriptif Analisis kelas XI Mipa SMA PGRI 2 Padang).

Menurut Dahlan (Kasih \& Haumi, 2017:14)bimbingan dan konseling selalu merupakan momen ilmu mendidik, ilmu pendidikan danbimbingan klien sebagai hal-hal esensialuntuk umat masa kini dan masa mendatang. Dalam kerangka pemikiran itulah dapat ditandaskan beberapa disiplin ilmu mendidik dan bimbingan klien mendapat tempat yangbukan saja wajar, akan tetapi bahkan esensialdalam pendidikan.

Prayitno (2004: 115) mengemukakan pendapatnya mengenai bimbingan Kelompok sebagai suatu kegiatan yang dilakukan oleh sekelompok orang dengan memanfaatkan dinamika kelompok, artinya semua orang yang menjadi anggota kelompok akan saling berinteraksi, bebas mengemukakan pendapat, dan saling bertukar fikiran mengenai informasi yang bermanfaat.

\section{Fungsi layanan bimbingan kelompok}

Terdapat beberapa fungsi layanan dalam bimbingan kelompok seperti fungsi pemahaman (memahami konseli), fungsi preventif (memberikan informasi agar tercegah dari masalah), fungsi pengembangan (mengembangkan potensi konseli), dan fungsi kuratif (memecahkan masalah). Dalam membuat desain RPL, konselor harus tahu dan paham fungsi layanan yang mana yang menjadi tujuan. (1) Tujuan layanan yaitu berisi tentang tujuan yang akan di capai dari hasil asesmen, (2) Sasaran layanan yaitu berisi kelas yang akan mendapatkanlayanan bimbingan kelompok, (3) Materi layanan yaitu berisi tentang tema atau topik materi yang akan di bahas untuk mencapai tujuan. (4) Sumber materi, (5) Metode Role Playing,(6) Media atau alat adalah perlengkapan yang digunakan dalam memberi layanan ke pada peserta didik, (7) Pelaksanaan, (8) Evaluasi adalah suatu langkah penting dalam manajemen pelayanan bimbingan dan konseling.

\section{Tahap-tahap bimbingan Kelompok}

Prayitno (Kardo,2015:86) menyatakan Tahap-tahap pelaksanaan bimbingan kelompok dengan menggunakan metode Role playing, sebagai berikut :

\section{1) Tahap pembentukan}

Tahap ini merupakan tahap pengenalan, tahap pelibatan diri atau tahap memasukkan diri ke dalam kehidupan suatu kelompok. Pada tahap ini para anggota saling memperkenalkan diri dan juga mengakrabkan diri. Pemimpin kelompok (konselor) memberikan penjelasan tentang bimbingan kelompok sehingga masing-masing anggota akan tahu apa arti dari bimbingan 
kelompok dan mengapa bimbingan kelompok harus dilaksanakan serta menjelaskan aturan main yang akan diterapkan dalam bimbingan kelompok.. konselor juga menyampaikan asas kerahasiaan kepada seluruh anggota agar orang lain tidak mengetahui permasalahan yang terjadi pada mereka.

2) Tahap peralihan

Tahap peralihan adalah "jembatan" antara tahap pembentukan dan tahap kegiatan. Setelah anggota kelompok merasa nyaman dengan kelompoknya dan muncul sikap saling menerima antar anggota maka anggota kelompok dapat segera memasuki kegiatan tahap ketiga dengan penuh kemauan dan kesukarelaan.

3) Tahap kegiatan

Tahap ini merupakan inti dari kegiatan kelompok. Anggota kelompok melaksanakan teknik bermain peran dalam bimbingan kelompok yang dipimpin oleh konselor. Permainan peran yang digunakan adalah permainan peran terstruktur. Kegiatan dimulai dengan membagikan skenario drama, kemudian konselor menjelaskan sekilas tentang cerita yang akan didramakan. Konselor dan anggota kelompok kemudian menentukan siapa yang akan bermain peran dan siapa yang akan menjadi pengamat.

Dalam bermain peran yang terpenting bukan bagus atau tidaknya pementasan drama tetapi inti dari tema/topik yang diangkat dalam drama dapat dipahami dan dicobaterapkan oleh anggota kelompok. Setelah dilakukan permainan peran anggota kelompok melakukan diskusi dipimpin oleh konselor. Dalam skenario juga terdapat petunjuk pengamat dan pedoman diskusi. Sehingga diskusi dapat dilakukan dengan batasan tema/topik yang diangkat.

4) Tahap pengakhiran

Ada beberapa hal yang dilakukan pada tahap ini, yaitu: (1)Pemimpin kelompok mengemukakan bahwa kegiatan akansegera diakhiri, (2)Pemimpin dan anggota kelompok mengemukakan kesan dan hasil-hasil kegiatan, (3)Membahas kegiatan lanjutan,(4)Pemimpin kelompok mengadakan penilaian segera mengenai pemahaman anggota kelompok terhadap tema yang dibahas, kenyamanan anggota kelompok ketika mengikuti kegiatan bimbingan dan rencana nyata anggota kelompok dalam melaksanakan hasil bimbingan kelompok yang telah dilakukan.(5)Tahap evaluasi Merupakan tahap hasil dari kegiatan bimbingan kelompok yang telah di laksanakan oleh pemimpin kelompok dan anggota kelompok dalam bimbingan kelompok.Dalam evaluasi program bimbingan konseling terdapat 2 jenis evaluasi, yaitu: evaluasi hasil dan evaluasi proses.

\section{Tujuan Layanan Bimbingan Kelompok dengan Menggunakan Metode Role Playing.}

Perencanaan program bimbingan dan konseling yang berkaitan dengan kecemasan berkomunikasipeserta didik bertujuan agar program yang kita buat yang di rancang oleh guru bimbingan dan konseling dapat mengatur waktu untuk menyusun, melaksanakan, menilai, dan menindak lanjuti program kegiatan bimbingan dan konseling. Agar dapat memberi arah untuk mencapai tujuan yang lebih jelas, dengan demikian akan lebih mudah mengetahui mencapai tujuan program, dan memudahkan untuk mengidentifikasi hambatan-hambatan yang ada. Pada saat guru bimbingan dan konseling membuat rencana pelaksanaan program, mereka menetapkan strategi untuk pencapaian program.

\section{KESIMPULAN}

Berdasarkan analisiss data dan pembahasan dapat diambil kesimpulan mengenai model bimbingan kelompok dengan menggunakan metode role playing dalam meningkatkan kedisiplinan peserta didik di kelas XI Mipa SMA PGRI 2 Padang. Temuan penelitian ini dapat disimpulkan sebagai berikut: 1) Secara umum profil kecemasan berkomunikasi peserta didik pada variabel keterampilan komunikasi verbal berada pada kategori cukup tinggi pada persentase 86,66\%. 2) Pelaksanaan layanan bimbingan kelompok dalam mengurangi kecemasan berkomunikasi peserta didik yang dilakukan guru BK belum memberikan hasil yang maksimal karena selama ini guru Bk kurang memberikan metode-metode yang bervariasi sehingga peserta didik menjadi bosan dan jenuh. 3) Model rancangan layanan bimbingan kelompok dengan menggunaka metode role playing dalam membantu mengurangi kecemasan berkomunikasi peserta didik dilihat dari penelitian yang peneliti 
lakukan di SMA PGRI 2 Padang. Guru BK belum pernah melakukan layanan bimbingan kelompok menggunakan metode role playing maka peneliti berharap agar Guru Bk dapat menerapkan metode role playing sehingga peserta didik dapat bersemangat mengikuti kegiatan bimbingan kelompok .

\section{DAFTAR RUJUKAN}

Dharmayanti,Putu Ari. 2013. Teknik Role Playing dalam MeningkatkanKeterampilan Komunikasi Interpersonal Siswa Smk. Jurnal Pendidikan dan Pengajaran. Singaraja : Universitas Pendidikan Genesha. Jilid 46, Nomor 3.

Jackson, V.A. 2011. Teaching Communi Cation Skill Using Role-Play; An Experience Based Guide For Educators. Journal of palliative medicine. 14 (6) : 775-780.

Kardo,Rici. 2015. Bimbingan Kelompok Sebagai Alternatif untuk Meningkatkan Komunikasi Interpersonal Siswa. Jurnal pelangi. STKIP PGRI sumatera barat. Vol.07 No.6 ISSN: 2085-1057 E-ISSN: 2460-3740.

Kasih,Fitria \& Haumi,Naufil. 2017. Profil Kompetensi Guru Bimbingan dan Konseling Dalam Pelayanan Kelompok di SMA Sumatera Barat.Jurnal Counseling Care. STKIP PGRI Sumatera Barat. Vol. 1 No.1. URL http://ejournal.stkip-pgri-sumbar.ac.id/index.php/counseling .ISSN : 2581-0650.

Larson \& Brown. 2007. Emotional Development in Adolescence: What Can Be Learned form A High School Theather Program. Journal Of Child Development. (Online).

Najlatun,N \& Galih, W. 2013. Penerapan Teknik Bermain Peran dalam Bimbingan Kelompok untuk Meningkatkan Kemampuan Komunikasi Interpersonal Siswa Kelas X Multimedia SMK IKIP Surabaya. Juornal Mahasiswa bimbingan konseling, 1 (1) : 61-78.

Prayitno,dkk. 2013. Dasar-dasar Bimbingan dan Konseling. Jakarta : PT Rineka cipta. Hal 307-308.

Sahputra, Dedi. 2020. Manajemen Komunikasi Suatu Pendekaan Komunikasi Communication Management A Communication Approach. Jurnal Simbolika. Program Studi Ilmu Komunikasi, Fakultas IImu Sosial dan IImu Politik, Universitas Medan Area, Indonesia. Vol. 06 No. 02. URL http://ojs.uma.ac.id/index.php/simbolika. ISSN 2442-9198, ISSN 2442-9996.

Sutirna. 2013. Bimbingan dan Konseling. Yogyakarta : CV Andi Offset.

Tohirin. 2011. Bimbingan dan Konseling di Sekolah dan Madrasah (Berbasis Integrasi). Jakarta : Raja Grafindo Persada 